\title{
Phosphorus absorption and use efficiency by Lotus spp. under water stress conditions in two soils: A pot experiment
}

\author{
Carolina Castillo $^{1}$, Hernán Acuña ${ }^{2 *}$, Erick Zagal ${ }^{1}$, and Luis Inostroza ${ }^{2}$
}

\begin{abstract}
The response to $\mathrm{P}$ and water deficiencies of forage Lotus species has not been sufficiently studied in the Andisol and Vertisol soil orders in Chile's marginal areas. A pot experiment under cover was carried out between October 2007 and March 2008 to study the effects of $\mathrm{P}$ and soil water availability (SWA) on DM production, $\mathrm{P}$ absorption, and $\mathrm{P}$ use efficiency in Lotus spp. The experiment included three Lotus (L. corniculatus L., L. tenuis Waldst. \& Kit. ex Willd., and L. uliginosus Schkuhr) species, two soils (Andisol and Vertisol), two contrasting P levels (low and high), and two SWA levels (10\% and 100\%). A completely randomized design with a $3 \times 2 \times 2 \times 2$ factorial arrangement with four replicates was used. Accumulated shoot and root DM, P absorption and efficiency, and arbuscular mycorrhizal (AM) colonization were measured. Phosphorus absorption was significantly higher in Andisol with $100 \%$ SWA and high $\mathrm{P}$ in the three species, which was reflected in $\mathrm{P}$ efficiency where the species exhibited higher P absorption efficiency (PAE) and P utilization efficiency (PUE) with low P, and mean of the three species with low $\mathrm{P}$ and high SWA. When the P level was low, L. uliginosus showed the highest PAE and L. corniculatus exhibited the highest PUE. Phosphorus efficiency was also influenced by AM colonization since on the average mycorrhization in the three species was significantly higher in the low P treatments. Differences existed among species for DM production, response to $\mathrm{P}, \mathrm{P}$ absorption, PAE, and PUE.
\end{abstract}

Key words: Lotus spp., volcanic soils, clay soils, mycorrhizal colonization.

\section{INTRODUCTION}

There are three perennial legumes of the Lotus genus that are important as forage in Chile: birdsfoot trefoil $(L$. corniculatus L.), narrow-leaf trefoil (L. tenuis Waldst. $\&$ Kit. ex Willd. syn. L. glaber), and greater lotus ( $L$. uliginosus Schkuhr syn. L. pedunculatus) (Acuña and Cuevas, 1999). These species are recognized as a useful alternative for soils with limitations (Seaney and Henson, 1970; Davis, 1991). Lotus corniculatus is a perennial legume, natural tetraploid, cross-pollinated, and with a taproot (Grant and Niizeki, 2009) that gives it the capacity to adapt to soils with poor drainage in winter and restricted water supply in summer. Lotus tenuis is a diploid species with a taproot (Miñón et al., 1990) that grows in soils with a wide range of $\mathrm{pH}$ and water and nutrient availability (Messa et al., 2008). It tolerates flooding, drought, and salinity; this gives it added value when comparing it with other legumes such as alfalfa (Medicago sativa L.) or white clover (Trifolium repens L.) (Striker et al., 2005; Acuña et al., 2010; Teakle et al., 2010). Lotus uliginosus is a diploid species with a shallow root system that gives

${ }^{1}$ Universidad de Concepción, Facultad de Agronomía, Av. Vicente Méndez 595, Chillán, Chile.

${ }^{2}$ Instituto de Investigaciones Agropecuarias INIA, Av. Vicente Méndez 515, Chillán, Chile. "Corresponding author (hacuna@inia.cl).

Received: 27 November 2012.

Accepted: 26 December 2012. rise to a network of rhizomes, stolons, and fibrous roots (Hernández et al., 2005). It grows well in low fertility soils with excess water and high acidity. The three Lotus species have the capacity to adapt to soils that are marginal for growing other crops. A fundamental characteristic of the three species is the capacity to efficiently absorb $\mathrm{P}$ in conditions of low $\mathrm{P}$ and water supply (Russelle et al., 1991); they show a great potential for adaptation to a number of abiotic stresses (Escaray et al., 2012). This is relevant since soil $\mathrm{P}$ deficiency is a limiting factor for agricultural production (Russelle et al., 1991; Buresh et al., 1997). Thus, it is important to study the ability of Lotus species to absorb $\mathrm{P}$ because of the low availability of this nutrient in most soils where the species are grown. This low availability in volcanic soils (Andisols) is caused by P fixation to amorphous clays (Takahashi and Anwar, 2007). Ortega and Rojas (1998) reported that most clays soils (Vertisols) exhibited low available P contents in a generally acidic environment along with low organic matter content. Phosphorus fixation in volcanic soil is generated by $\mathrm{Al}$ adsorption by amorphous clays such as allophane and imogolite and 1:1 crystalline clay minerals in acid medium.

In the area covered by the soil types described above where Lotus spp. could be introduced, the water balance (potential evaporation vs. rainfall) is negative, and water for irrigation is scarce for 6-mo (November to April). Therefore, pastures must endure drought periods between spring and summer in Mediterranean climates, which 
affect their persistence and productivity. On the other hand, soil water status impacts P availability (Wittenmayer and Merbach, 2005).

Plants have developed various strategies to more efficiently absorb soil $\mathrm{P}$ in constrained environments (Bolan et al., 1997; Mendoza and Pagani, 1997). These strategies can be grouped into two categories: (i) one involves physiological mechanisms to increase $\mathrm{P}$ use, and (ii) another is related to symbiotic associations between plant and mycorrhizal fungi, which increased capacity to capture and translocate P (Karandashov and Bucher, 2005).

The hypothesis of this research was that Lotus species are able to successfully adapt to the constraints of Andisol and Vertisol, particularly low P availability, thus improving $\mathrm{P}$ absorption and efficiency and low SWA. Therefore, the objective of this study was to evaluate the response to $\mathrm{P}$ in $\mathrm{DM}$ production and $\mathrm{P}$ absorption and use efficiency by Lotus spp. under contrasting soil $\mathrm{P}$ and water availability conditions.

\section{MATERIALS AND METHODS}

\section{Establishment and experimental design}

The experiment was carried out in the Centro Regional de Investigación (INIA) Quilamapu, Biobío Region, Chile in pots under cover between October 2007 and March 2008. Treatments corresponded to 24 factorial combinations of three species: L. corniculatus (Lc) cv. Quimey, L. tenuis (Lt), cv. Pampa INTA, and L. uliginosus (Lu) cv. Sunrise; two soils: Andisol (A) and Vertisol (V); two soil P levels: low $\mathrm{P}$ (P not applied), and high $\mathrm{P}$ (P applied at $40 \mathrm{mg} \mathrm{P} \mathrm{kg}^{-1)}$; and two SWA levels: $10 \%$ and $100 \%$. The experimental design was completely randomized with four replicates.

Pots were PVC cylinders with a diameter of $110 \mathrm{~mm}$ and depth of $150 \mathrm{~mm}$ fitted with a cover at the base with a hole in the center to drain excess water. Ten seeds per pot were sown on 24 September 2007. Pots were maintained in a greenhouse until germination and then thinned to five plants per pot. Neither the seeds nor the seedlings were inoculated with Rhizobium spp.To standardize N supply, $\mathrm{N}$ was applied once a week from 26 September 2007 to 5 March 2008 in the Andisol and from 26 September 2007 to 12 April 2008 in the Vertisol. Other nutrients were not applied to preserve the soil's natural chemical condition. The pots were put outdoors with $50 \%$ artificial cover (white raschel mesh) on 15 November 2007.

\section{Soil physical characterization and water availability treatments}

The soils selected for this study were an Andisol of the Pueblo Seco series: medial over sandy skeletal, amorphic, thermic Humic Haploxerands and a Vertisol of the Quella series: very fine, smectitic, thermic Aquic Durixererts (Stolpe, 2006). Undisturbed cores were collected by driving PVC cylinders (pots) into $0-15 \mathrm{~cm}$ strata, which did not affect soil physical characteristics. The two contrasting SWA levels, $10 \%$ and $100 \%$, were defined by the water retention curve for each soil (Table 1), determined by Klute's method (Klute, 1986). Water levels for each treatment were maintained during the experiment by weighing the pots daily and adding water to reach the corresponding weight. Water availability treatments started on 26 November 2007 and were suspended on 27 December 2007 for both Andisol and Vertisol; treatments were resumed on 26 January 2008 (Andisol) and 10 February 2008 (Vertisol). The SWA treatments for each soil were resumed on different dates because the Lotus recovery period after cutting the first shootswas shorter in the Andisol.

\section{Soil chemical characterization, nutrient application, and phosphorus treatments}

The initial chemical characteristics of the Andisol and Vertisol in the $0-20 \mathrm{~cm}$ strata are shown in Table 1. The high $\mathrm{P}$ treatment applied $\mathrm{P}$ to the pots with a micropipette as $85 \% \mathrm{H}_{3} \mathrm{PO}_{4}$ at rates of $7.83 \mathrm{~mL}$ in the Andisol and 4.34 $\mathrm{mL}$ in the Vertisol to reach a concentration of $40 \mathrm{mg} \mathrm{kg}^{-1}$ available $\mathrm{P}$ in both soils. Phosphorus was applied at a depth of $80 \mathrm{~mm}$ in ten homogeneously distributed points in the pot. The quantity of $\mathrm{P}$ was calculated by determining $\mathrm{P}$ buffering capacity (P fixation coefficient, PFC) for both soils. This coefficient establishes the quantity of $\mathrm{P} \mathrm{kg}$ that must be added to 1 ha of soil to increase Olsen $\mathrm{P}$ by 1 $\mathrm{mg} \mathrm{kg}^{-1}$ up to a depth of $200 \mathrm{~mm}$. To verify that it reached this concentration, a new soil $\mathrm{P}$ analysis was carried out

Table 1. Soil physical and chemical characteristics in the $0-20 \mathrm{~cm}$ depth.

\begin{tabular}{|c|c|c|}
\hline Parameter & Andisol & Vertisol \\
\hline Texture $^{1}$ & Loam & Silty clay loam \\
\hline Bulk density ${ }^{2}, \mathrm{~g} \mathrm{~cm}^{-3}$ & 0.84 & 1.43 \\
\hline Water at $30 \mathrm{kPa}, \%^{3}$ & 43.85 & 33.33 \\
\hline Water at $1500 \mathrm{kPa}, \%^{3}$ & 22.24 & 15.47 \\
\hline Soil water availability, $\%$ w/w & 21.61 & 17.86 \\
\hline $\mathrm{pH}$ (water 1:2.5) & 6.3 & 6.0 \\
\hline Organic matter ${ }^{4}, \%$ & 14.0 & 2.2 \\
\hline $\mathrm{PFC}^{5}$ & 23.2 & 11.3 \\
\hline $\mathrm{N}-\mathrm{NO}_{3}{ }^{6}, \mathrm{mg} \mathrm{kg}^{-1}$ & 10.0 & 8.3 \\
\hline Olsen $\mathrm{P}, \mathrm{mg} \mathrm{kg}^{-1}$ & 7.0 & 4.0 \\
\hline $\mathrm{K}, \mathrm{mg} \mathrm{kg}^{-1}$ & 165.4 & 45.3 \\
\hline $\mathrm{Ca}, \mathrm{cmol} \mathrm{kg}^{-1}$ & 8.7 & 6.6 \\
\hline $\mathrm{Mg}, \mathrm{cmol} \mathrm{kg}^{-1}$ & 1.1 & 3.1 \\
\hline $\mathrm{K}, \mathrm{cmol} \mathrm{kg}^{-1}$ & 0.4 & 0.1 \\
\hline $\mathrm{Na}, \mathrm{cmol} \mathrm{kg}^{-1}$ & 0.1 & 0.3 \\
\hline $\mathrm{Al}, \mathrm{cmol} \mathrm{kg}^{-1}$ & 0.01 & 0.03 \\
\hline $\mathrm{ECEC}^{7}$ & 10.3 & 10.2 \\
\hline $\mathrm{Al}$ saturation, $\%$ & 0.1 & 0.3 \\
\hline $\mathrm{Zn}, \mathrm{mg} \mathrm{kg}^{-1}$ & 0.3 & 0.4 \\
\hline $\mathrm{Fe}, \mathrm{mg} \mathrm{kg}^{-1}$ & 33.6 & 87.5 \\
\hline $\mathrm{Cu}, \mathrm{mg} \mathrm{kg}^{-1}$ & 1.0 & 3.7 \\
\hline $\mathrm{Mn}, \mathrm{mg} \mathrm{kg}^{-1}$ & 3.4 & 81.8 \\
\hline $\mathrm{B}, \mathrm{mg} \mathrm{kg}^{-1}$ & 0.7 & 0.2 \\
\hline $\mathrm{S}, \mathrm{mg} \mathrm{kg}^{-1}$ & 9.5 & 5.3 \\
\hline
\end{tabular}

${ }^{1}$ Hydrometer method; ${ }^{2}$ Clod method; ${ }^{3}$ Klute's method (Klute, 1986); ${ }^{4}$ Wet digestion of organic matter; ${ }^{5} \mathrm{Phosphorus} \mathrm{Fixation} \mathrm{Coefficient,} \mathrm{kg} \mathrm{ha}^{-1}$ of $\mathrm{P}$ that must be applied to increase available soil $\mathrm{P}$ by $1 \mathrm{mg} \mathrm{kg}^{-1}$; ${ }^{6}$ Extraction with $\mathrm{K}_{2} \mathrm{SO}_{4} 0.5 \mathrm{M}$ and colorimetry; ${ }^{7}$ Efective cation exchange capacity. 
1-mo after application. These analyses showed a mean of $38.1 \mathrm{mg} \mathrm{P} \mathrm{kg}^{-1}$ for Andisol and $39.3 \mathrm{mg} \mathrm{P} \mathrm{kg}^{-1}$ for Vertisol. The low P level (P not applied) was $7.04 \mathrm{mg} \mathrm{P} \mathrm{kg}^{-1}$ in the Andisol and $4.03 \mathrm{mg} \mathrm{P} \mathrm{kg}^{-1}$ in the Vertisol.

\section{Measurements}

Shoot and root DM. Shoot DM (leaves, stems, and petioles) was determined in two cuttings and as a total of both cuttings $\left(1^{\text {st }}\right.$ cutting shoot DM, $2^{\text {nd }}$ cutting shoot DM, and total shoot DM); root DM was determined at the end of the experiment. Samples were dried in a forced air oven at $65{ }^{\circ} \mathrm{C}$ until a constant weight was reached. The first cutting was made at a height of $2.5 \mathrm{~cm} 93 \mathrm{~d}$ after sowing (das) in both soils; the second cutting was at 165 das in the Andisol and 205 das in the Vertisol. The second cutting in the Vertisol was delayed because plants in this soil developed more slowly than in the Andisol and cutting was postponed so that plants in both soils would exhibit the same degree of development.

Phosphorus absorption and utilization efficiency. Shoot $\mathrm{P}$ concentration (SPC) was determined in the laboratory by the calcination method and colorimetry of phosphovanadomolybdate (Sadzawka et al., 2007). Phosphorus absorption (PA) was calculated by multiplying SPC by shoot DM: P absorption efficiency (PAE, mg P absorbed pot $^{-1} / \mathrm{mg} \mathrm{kg}^{-1}$ Olsen P) was calculated by dividing PA by soil $\mathrm{P}$ availabllity expressed as $\mathrm{mg} \mathrm{kg}^{-1}$ Olsen $\mathrm{P}$. Phosphorus utilization efficiency (PUE, g DM pot $^{-1} / \mathrm{g}$ absorbed $\mathrm{P} \mathrm{pot}^{-1}$ ) was calculated by dividing accumulated $\mathrm{DM}$ per pot by absorbed $\mathrm{P}$ per pot. This expresses the quantity of DM produced per unit of absorbed P (Ahmad et al., 2001; Acuña and Inostroza, 2012).

Arbuscular mycorrhizal colonization. Root samples were taken from each pot to determine arbuscular mycorrhizal (AM) colonization after separating the roots from the soil. This parameter was determined by counting the mycorrhized apices of three secondary roots chosen at random, which were dispersed on a petri dish with a grid where the interceptions with the lines were counted (Giovannetti and Mosse, 1980; Steubing et al., 2002). Arbuscular mycorrhizae were observed with a stereomicroscope. Root material was dyed with aniline blue in an acidic medium (lactic acid) after prior discoloration of the root with an alkaline $\mathrm{H}_{2} \mathrm{O}_{2}+\mathrm{NH}_{4} \mathrm{OH}$ solution for $10-15 \mathrm{~min}$.

\section{Statistical analysis}

Analysis of variance (ANOVA) was performed to determine the effects of the treatments by the General Linear Model (GLM) procedure of the Statistics Analysis Systems package (SAS, 2004). Data were transformed when they did not meet the ANOVA assumptions. Standard error values are shown to compare the means when the main effects or the interaction were found to be significant.

\section{RESULTS}

The $\mathrm{F}$ values and levels of significance for all the sources of variation, species, soil, SWA, P, and species $\times$ soil, species $\times$ SWA, species $\times \mathrm{P}$, soil $\times$ SWA, soil $\times \mathrm{P}$, and SWA $\times \mathrm{P}$ interactions of ANOVA for total shoot DM, root $\mathrm{DM}$, shoot $\mathrm{P}$ concentration, shoot $\mathrm{P}$ absorption, $\mathrm{PAE}$, PUE, and AM colonization are shown in Table 2.

\section{Shoot and root DM}

Shoot and root DM were higher in the Andisol (Figures 1a and 1c). Lotus corniculatus and Lt exhibited a higher reduction in shoot DM than Lu (Figure 1a). The pattern is similar for root DM, but Lc exhibited the sharpest decrease in the Vertisol (Figure 1c). When comparing these forage species in the two soil $\mathrm{P}$ conditions (low and high $\mathrm{P}$ ), it is observed that Lc and Lt increased $(\mathrm{P}<0.001)$ shoot DM production when $\mathrm{P}$ increased, while $\mathrm{Lu}$ production was equal at the two P levels (Figure 1b). Figure 1d shows that root DM accumulation was lower $(\mathrm{P}<0.001)$ in the Vertisol at both SWA levels. Yield with $10 \%$ SWA was significantly lower in both soils. Finally, Figure 1e shows

Table 2. ANOVA, F-values, and level of significance for species, soil, soil water availability, $P$, and double interactions.

\begin{tabular}{|c|c|c|c|c|c|c|c|c|}
\hline $\begin{array}{l}\text { Sources of } \\
\text { variation }\end{array}$ & df & $\begin{array}{l}\text { Total shoot } \\
\text { DM }\end{array}$ & $\begin{array}{l}\text { Root } \\
\text { DM }\end{array}$ & $\begin{array}{c}\text { Shoot P } \\
\text { concentration }\end{array}$ & $\begin{array}{c}\text { Shoot P } \\
\text { absorption }\end{array}$ & PAE & PUE & $\underset{\text { colonization }}{\mathrm{AM}}$ \\
\hline Species & 2 & $14.22^{* * * *}$ & $16.32^{* * * *}$ & $52.79^{* * * *}$ & $73.85^{* * * *}$ & $59.06^{* * *}$ & $46.49^{* * * *}$ & $299.58^{* * *}$ \\
\hline Soil & 1 & $186.65^{* * * *}$ & $278.71^{\text {****** }}$ & $27.18^{* * * *}$ & $372.60^{* * * *}$ & $147.81^{* * * *}$ & $31.81^{* * * *}$ & $48.36^{* * *}$ \\
\hline SWA & 1 & $129.54^{* * * *}$ & $317.82^{* * * *}$ & $0.63^{\mathrm{NS}}$ & $226.47^{* * * * *}$ & $220.18^{* * * *}$ & $1.86^{\mathrm{NS}}$ & $64.67^{* * *}$ \\
\hline $\mathrm{P}$ & 1 & $22.53^{* * * *}$ & $27.52^{* * * *}$ & $335.58^{* * *}$ & $297.47^{* * * *}$ & $754.48^{* * * *}$ & $318.82^{* * * *}$ & $226.69^{* * * *}$ \\
\hline Species $\times$ Soil & 2 & $18.91^{* * * *}$ & $15.24^{* * * *}$ & $28.76^{* * * *}$ & $11.73^{* * * *}$ & $3.74^{*}$ & $27.44^{* * * *}$ & $3.99^{*}$ \\
\hline Species $\times$ SWA & 2 & $0.35^{\mathrm{NS}}$ & $5.70^{* *}$ & $0.72^{\mathrm{NS}}$ & $5.39^{* * *}$ & $0.37^{\mathrm{NS}}$ & $0.81^{\mathrm{NS}}$ & $0.62^{\mathrm{NS}}$ \\
\hline Species $\times \mathrm{P}$ & 2 & $6.41^{* * *}$ & $2.11^{\mathrm{NS}}$ & $11.50^{* * * *}$ & $15.94^{* * * *}$ & $12.13^{* * *}$ & $6.80^{* *}$ & $1.81^{\mathrm{NS}}$ \\
\hline Soil $\times$ SWA & 1 & $3.49^{\mathrm{NS}}$ & $56.69^{* * *}$ & $9.27^{* *}$ & $13.64^{* * *}$ & $0.68^{\mathrm{NS}}$ & $12.45^{* * * *}$ & $0.29^{\mathrm{NS}}$ \\
\hline Soil $\times \mathrm{P}$ & 1 & $1.19^{\mathrm{NS}}$ & $0.18^{\mathrm{NS}}$ & $19.20^{* * * *}$ & $8.13^{* *}$ & $5.37^{*}$ & $30.26^{* * * *}$ & $8.70^{* * *}$ \\
\hline $\mathrm{SWA} \times \mathrm{P}$ & 1 & $0.54^{\mathrm{NS}}$ & $12.82 * * *$ & $3.04^{\mathrm{NS}}$ & $13.15^{* * * *}$ & $41.48^{* * * *}$ & $4.33^{*}$ & $1.51^{\mathrm{NS}}$ \\
\hline $\begin{array}{l}\text { Data } \\
\text { transformation }\end{array}$ & & & $\log 10(x+1)$ & $\log 10(x+1)$ & Arcsine $\sqrt{ } \mathrm{p}$ & $\log 10(x+1)$ & $\log 10(x+1)$ & Arcsine $\sqrt{ } \mathrm{p}$ \\
\hline
\end{tabular}

PAE: phosphorus absorption efficiency; PUE: phosphorus utilization efficiency; AM: arbuscular mycorrhizal; SWA: Soil water availability. ${ }^{*} \mathrm{P}<0.05$; ${ }^{* *} \mathrm{P}<0.01$; ${ }^{* * * *} \mathrm{P}<0.001$; NS: non significant. 

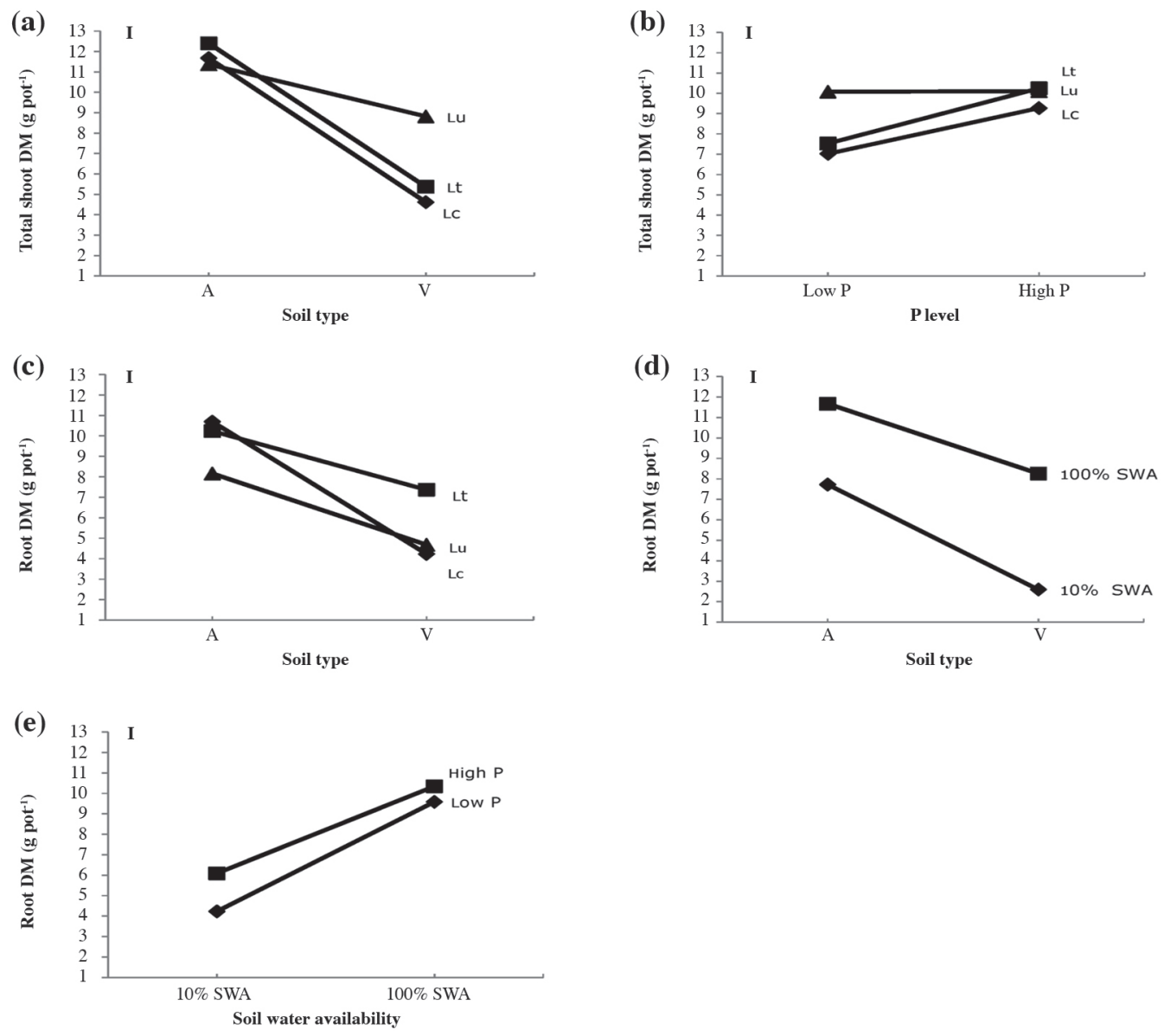

A: Andisol; V: Vertisol; Lc: Lotus corniculatus; Lt: Lotus tenuis; Lu: Lotus uliginosus.

Figure 1. Total shoot DM interactions: (a) species $\times$ soil $(P<0.001)$ and (b) species $\times P(P<0.01)$. Root DM interactions: $(c)$ species $\times$ soil $(P$ $<0.001)$, (d) soil $\times$ soil water availability (SWA) $(\mathrm{P}<0.001)$, and (e) SWA $\times \mathbf{P}(\mathrm{P}<0.001)$. Vertical bars are the standard error of the mean to compare means of the interaction of principal factors.

that there is a positive effect on root DM accumulation of high P at low SWA.

\section{Shoot phosphorus concentration and absorption}

Lotus uliginosus exhibited higher shoot $\mathrm{P}$ concentration $(\mathrm{P}$ $<0.001)$ in the Andisol than in the Vertisol. The other two species revealed similar concentrations in both soils (Figure 2a). Adding more $P$ to the soil increased $(P<0.001)$ shoot $\mathrm{P}$ concentration in the three species (Figure $2 \mathrm{~b}$ ). Shoot $\mathrm{P}$ concentration was lower in the Vertisol $(\mathrm{P}<0.001)$ at $100 \%$ SWA, but there were no differences between the two soils at $10 \%$ (Figure 2c). The soil $\times \mathrm{P}$ interaction (Figure $2 \mathrm{~d}$ ) indicates that shoot $\mathrm{P}$ concentration of plants sown in the Vertisol were significantly lower than those sown in the Andisol when P was not added to the soil.

Absorbed $\mathrm{P}$ for the three species was higher $(\mathrm{P}<0.05)$ in the Andisol and lower in Lc (Figure 3a). The three species absorbed more $\mathrm{P}(\mathrm{P}<0.05)$ when SWA was $100 \%$, and Lc absorbed less $\mathrm{P}$ than the other two species in both SWA levels (Figure $3 b$ ). The three species increased $P$ absorption when the soil P level increased; P absorption levels for Lc were significantly lower than $\mathrm{Lt}$ and $\mathrm{Lu}$ at the two soil $\mathrm{P}$ levels (Figure 3c). On the average, the three species increased $(\mathrm{P}<0.001)$ their $\mathrm{P}$ absorption when SWA increased from $10 \%$ to $100 \%$ and the $10 \%$ SWA values were significantly lower (Figure 3d). Absorption was higher with high $\mathrm{P}$ in both soils (Figure 3e), but values obtained in the Andisol were significantly higher. Mean $\mathrm{P}$ absorption of the three species was higher $(\mathrm{P}<$ 0.001) with high P and high SWA (Figure 3f).

\section{Phosphorus absorption and utilization efficiency}

Figure 4a shows that PAE was higher in the Andisol than the Vertisol and increased more in $\mathrm{Lt}$ than in the other two species, while Lc increased the least. The three species at the two levels of soil available $\mathrm{P}$ show higher PAE at the low P level (Figure 4b). The difference was similar in $\mathrm{Lc}$ and $\mathrm{Lt}$, but the difference due to soil $\mathrm{P}$ for $\mathrm{Lu}$ was higher (Figure 4b). It was found that PAE was higher in the Andisol at the two available P levels (Figure 4c). The 

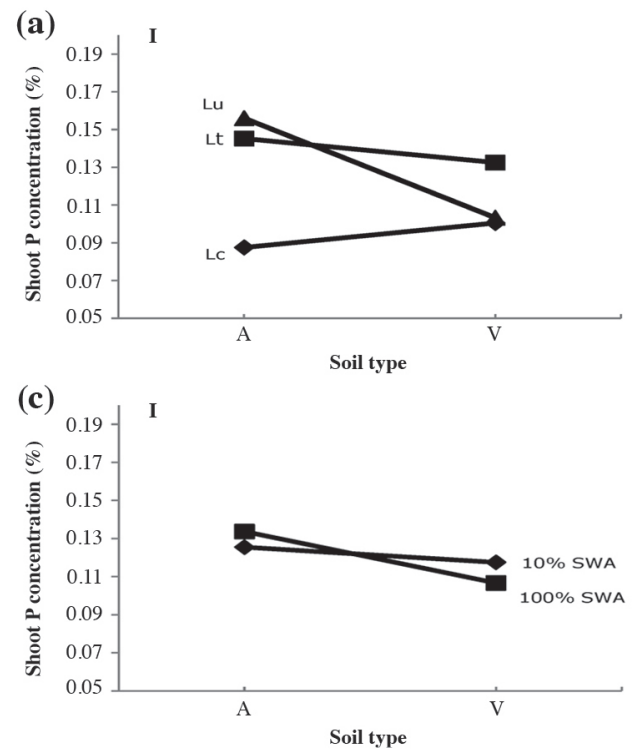
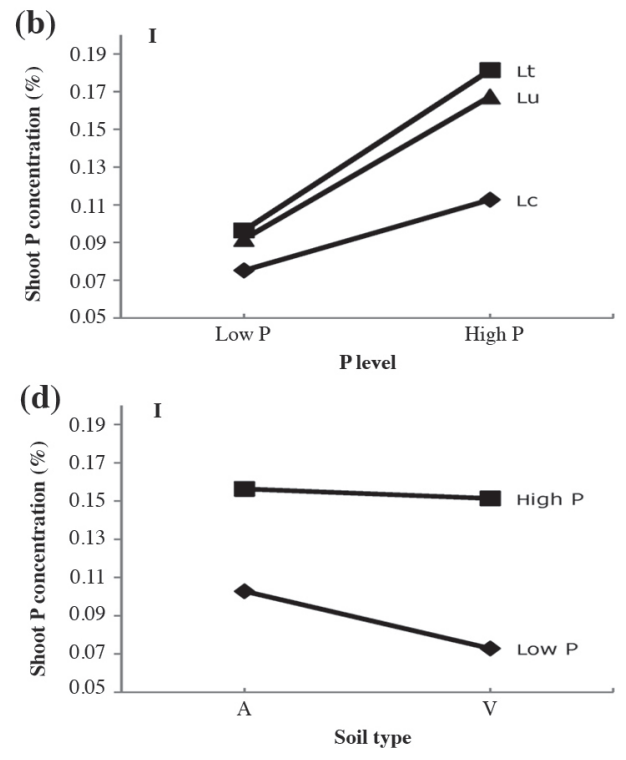

A: Andisol; V: Vertisol; Lc: Lotus corniculatus; Lt: Lotus tenuis; Lu: Lotus uliginosus.

Figure 2. Shoot $P$ concentration interactions: (a) species $\times$ soil $(P<0.001)$, (b) species $\times P(P<0.001)$, (c) soil $\times$ soil water availability (SWA) $(P$ $<0.01)$, and $(\mathrm{d})$ soil $\times \mathrm{P}(\mathrm{P}<\mathbf{0 . 0 0 1})$. Vertical bars are the standard error of the mean to compare means of the interaction of principal factors.
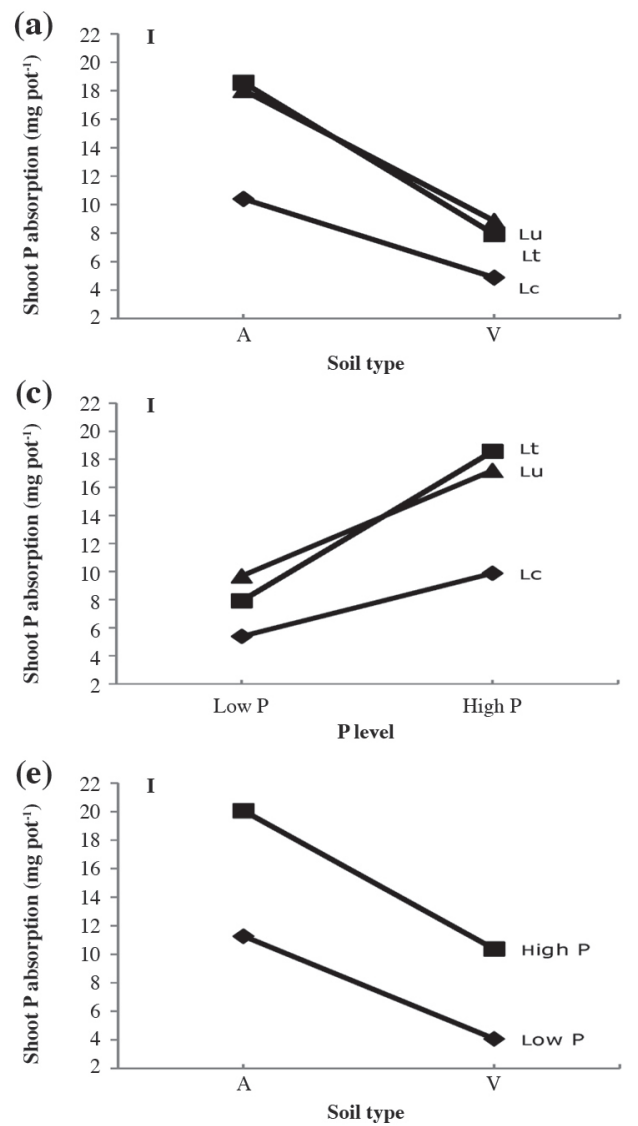
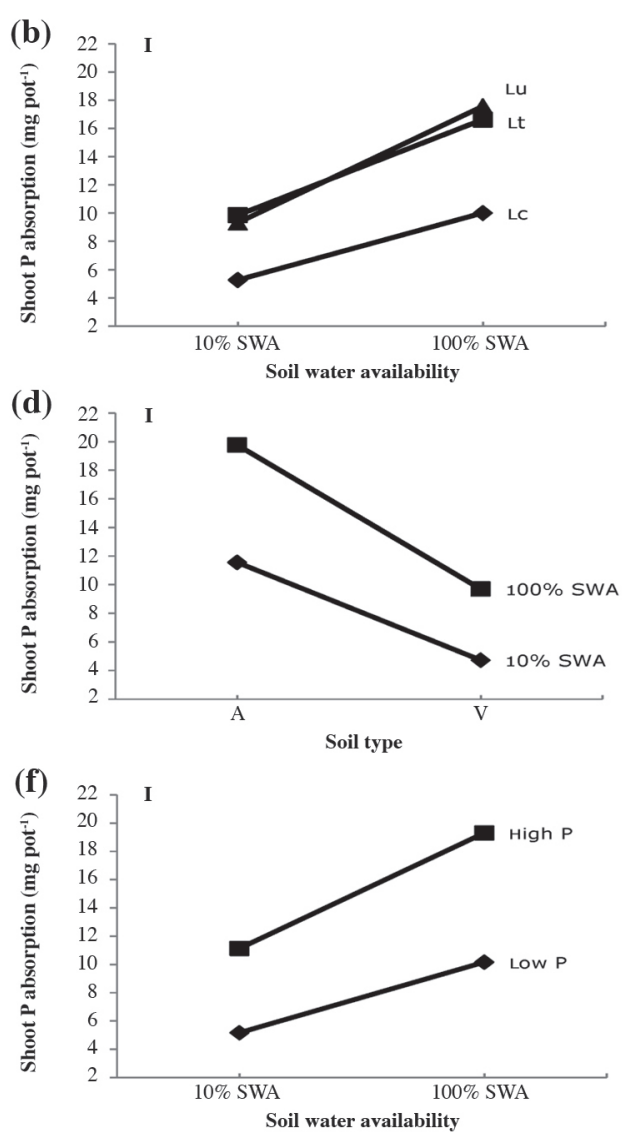

A: Andisol; V: Vertisol; Lc: Lotus corniculatus; Lt: Lotus tenuis; Lu: Lotus uliginosus.

Figure 3. Shoot $P$ absorption interactions: (a) species $\times$ soil $(P<0.001)$, (b) species $\times$ soil water availability $(\mathrm{SWA})(\mathrm{P}<0.01)$, (c) species $\times \mathbf{P}(\mathrm{P}<$ $0.001)$, (d) soil $\times$ SWA $(P<0.001)$, (e) soil $\times P(P<0.01)$, and (f) SWA $\times P(P<0.001)$. Vertical bars are the standard error of the mean to compare the interaction of principal factors. 

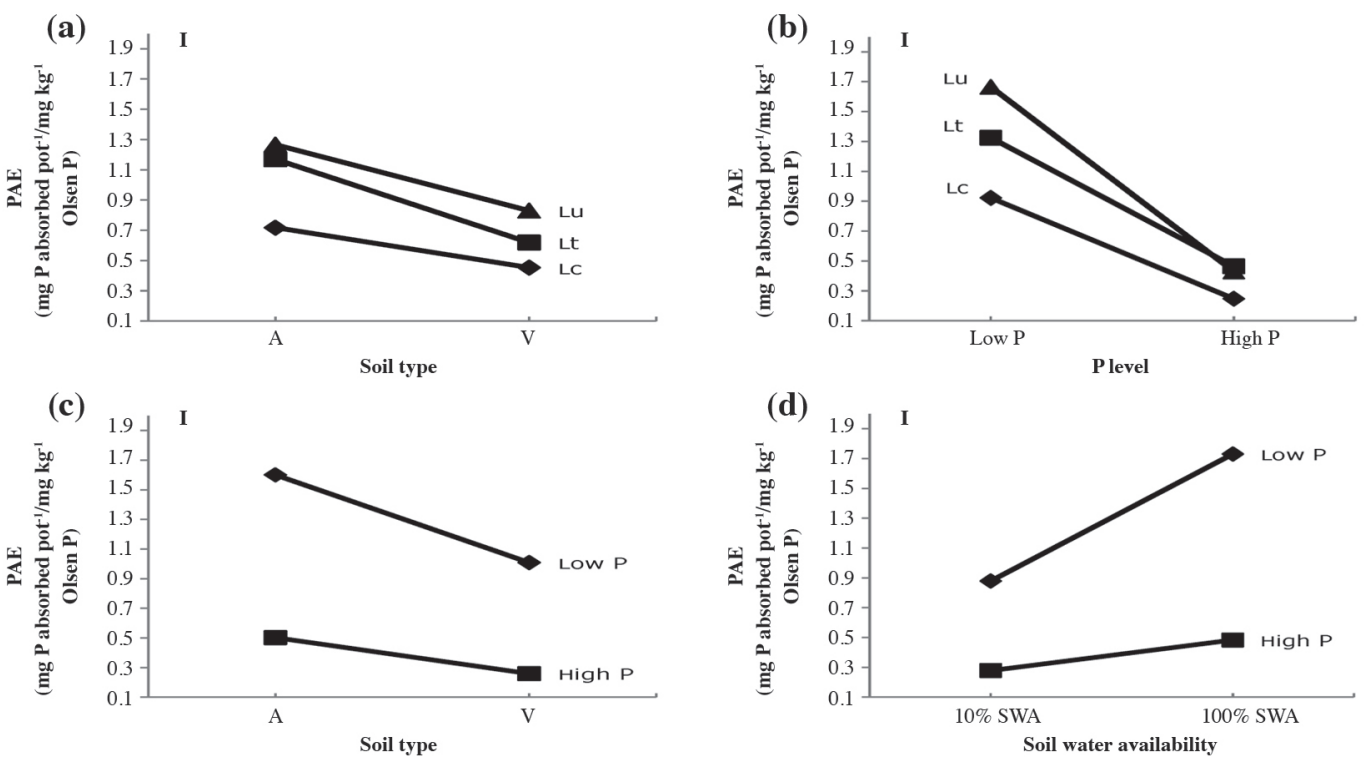

A: Andisol; V: Vertisol; Lc: Lotus corniculatus; Lt: Lotus tenuis; Lu: Lotus uliginosus.

Figure 4. Phosphorus absorption efficiency (PAE) interactions: (a) species $\times$ soil $(P<0.05)$, (b) species $\times P(P<0.001)$, (c) soil $\times P(P<0.05)$, and (d) soil water availability (SWA) $\times \mathbf{P}(\mathbf{P}<\mathbf{0 . 0 0 1})$. Vertical bars are the standard error of the mean to compare the interaction of principal factors.

$\mathrm{SWA} \times \mathrm{P}$ interaction also shows that PAE was higher with low $\mathrm{P}$ in the two SWA levels, but particularly higher with low $\mathrm{P}$ at $100 \%$ SWA (Figure $4 \mathrm{~d}$ ).

The species $\times$ soil interaction shows that $\mathrm{Lu}$ had the lowest PUE in the Andisol and the highest in the Vertisol whereas Lc exhibited similar PUE in both soils, and Lt slightly improved its PUE when the Andisol was compared with the Vertisol (Figure 5a). Phosphorus utilization efficiency in the three species under low available P vs. high available P (Figure 5b) was significantly higher with low P. The decrease for $\mathrm{Lu}$ is the most noteworthy. Phosphorus utilization efficiency was maintained in both soils at a similar level with $10 \%$ SWA, while it was significantly higher in the Vertisol with $100 \%$ SWA (Figure 5c). There was no difference between soils when $\mathrm{P}$ was high (Figure 5d). However, PUE was much higher in the Vertisol when $\mathrm{P}$ was low.

\section{Arbuscular mycorrhizal colonization}

The three species tended to exhibit a lower AM colonization in the Vertisol (Figure 6a). The most important decrease was observed in Lc, which exhibited the highest AM colonization in both soils. Lotus uliginosus achieved the lowest values and $\mathrm{Lt}$ had intermediate values. The mycorrhizal colonization mean value of the three species was higher in both soils when $\mathrm{P}$ was low, and the Vertisol values were lower than the Andisol at both P levels (Figure 6b).

\section{DISCUSSION}

Results of this experiment show that practically all the factors under study significantly affected DM production,
PAE, and PUE. Moreover, it is observed that there are multiple interactions among the factors. There is also a close relationship between AM colonization and the abovementioned effects, especially expected $\mathrm{P}$ absorption and utilization efficiency (Miyasaka and Habte, 2001; Feng et al., 2003; Mendoza et al., 2005). This agrees with the literature where results of pot experiments are reported to have responses that are more marked than those occurring in the field (Smith et al., 2011). It must be pointed out that there is a considerable restriction for full root development in pots, at least of the size used in this experiment, given their limited depth and restricted soil volume. This becomes more relevant when species with different root architecture are compared as in the present experiment. A more rapid depletion of $\mathrm{P}$ availability might be expected than in field conditions; this situation would also affect other nutrients and could indirectly affect the response to soil physical and chemical conditions that have an impact on root development, moisture retention, $\mathrm{P}$ absorption, and nutrients in general. Periodic applications of mineral fertilizer for plant $\mathrm{N}$ availability did not allow $\mathrm{N}_{2}$ fixation processes which involve proton release to the root-soil interface (Tang and Rengel, 2003). Increased acidification of the rhizosphere by roots is a widespread response to P deficiency (Neumann and Römheld, 1999; Hinsinger, 2001), which can affect the results of this experiment.

\section{Shoot and root DM}

Results are largely explained by the difference in physical properties between soils used in the experiment (Table 2), especially texture, bulk density, growth habit, and root 

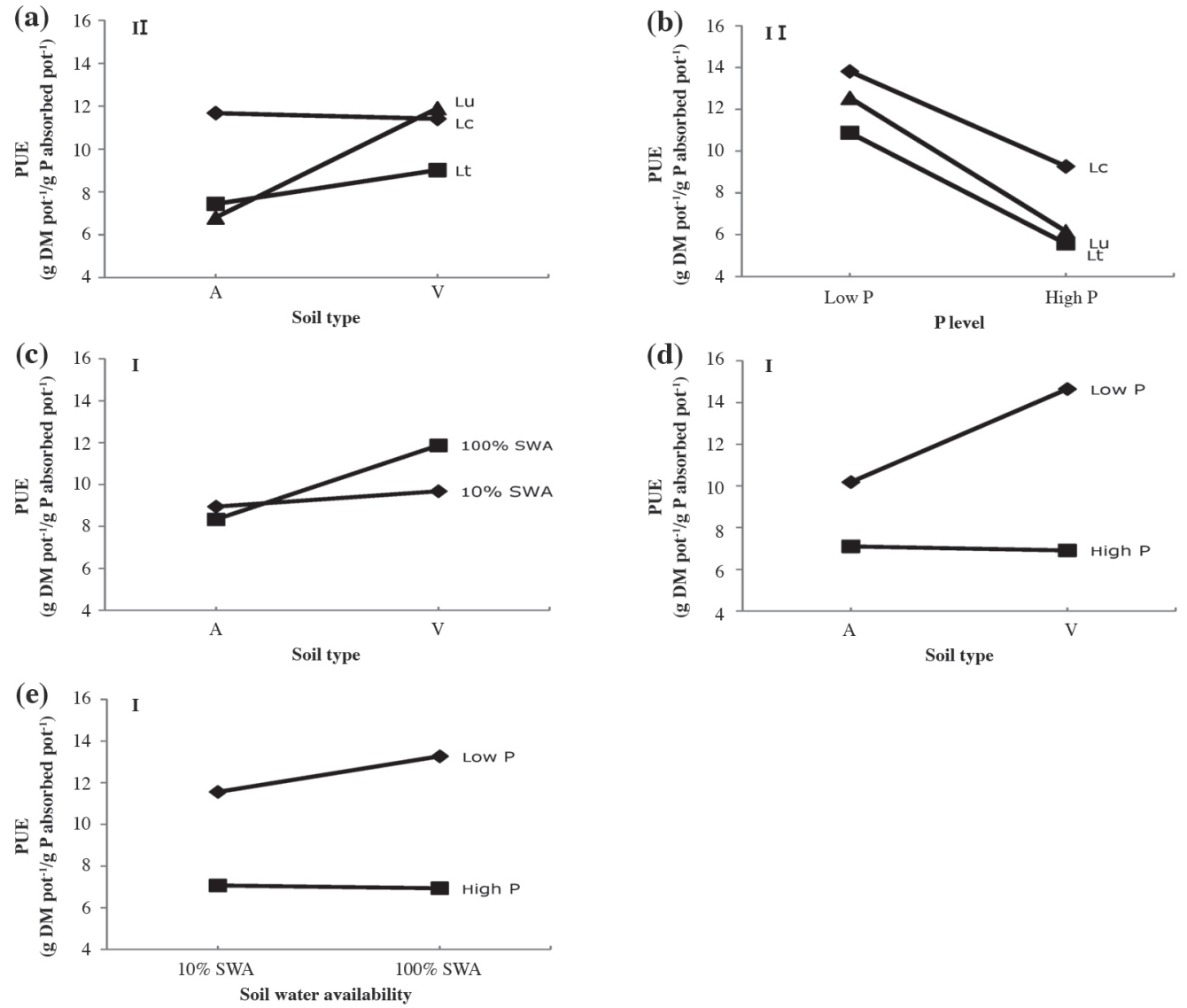

A: Andisol; V: Vertisol; Lc: Lotus corniculatus; Lt: Lotus tenuis; Lu: Lotus uliginosus.

Figure 5. Phosphorus utilization efficiency (PUE) interactions: (a) species $\times$ soil $(\mathbf{P}<0.001)$, (b) species $\times \mathbf{P}(\mathbf{P}<0.01)$, (c) soil $\times$ soil water availability $(\mathrm{SWA})(\mathrm{P}<0.001)$, (d) soil $\times \mathrm{P}(\mathrm{P}<\mathbf{0 . 0 0 1})$, and (e) soil $\times$ SWA. Vertical bars are the standard error of the mean to compare the interaction of principal factors.
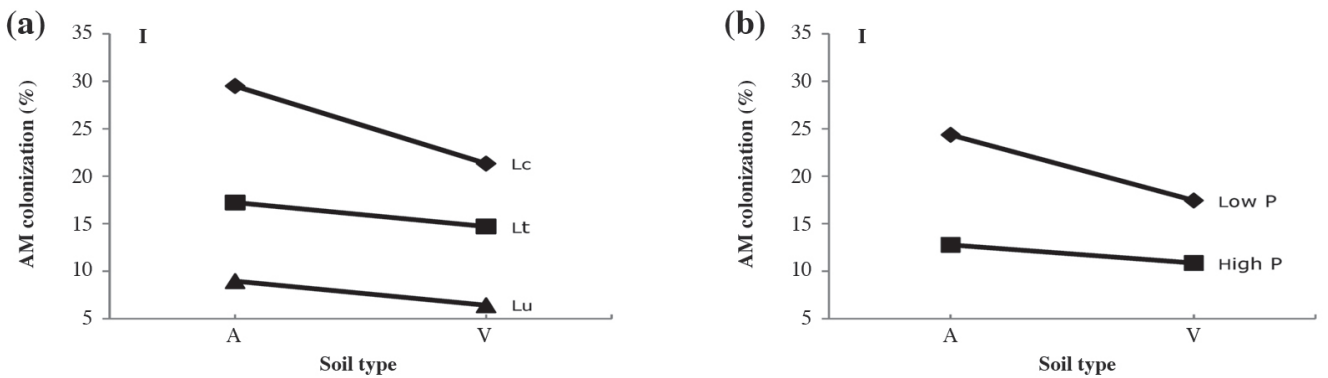

A: Andisol; V: Vertisol; Lc: Lotus corniculatus; Lt: Lotus tenuis; Lu: Lotus uliginosus.

Figure 6. Arbuscular mycorrhizal $(\mathrm{AM})$ colonization interactions: (a) species $\times$ soil $(\mathrm{P}<0.05)$ and $(\mathrm{b})$ soil $\times \mathrm{P}(\mathrm{P}<0.01)$. Vertical bars are the standard error of the mean to compare the interaction of principal factors.

structure of the species under study. Root growth of Lc and $\mathrm{Lt}$ would have been affected by the fine texture and high microporosity of the Vertisol (Puentes et al., 1992), thus preventing the same growth that plants achieved in the Andisol, and exhibiting particular physical, chemical, and microbiological properties. These properties facilitate optimal development of deep roots in both species (Rahman et al., 2008). This occurred when the roots from the soil in this experiment were manually separated. The roots in the Andisol explored a greater soil volume so that plants had better access to water and nutrients in the pot allowing greater foliage growth. On the contrary, Lu roots 
were profusely distributed only in the most superficial strata of the pot because it has a non-pivotal root system (Hernández et al., 2005). It shows a significantly lower decrease in shoot growth than Lc and Lt (Figure 1a) betweenthe Andisol and Vertisol; this demonstrates its greater genetic adaptation to a more restrictive soil, such as low fertility (Kaiser and Heath, 1990). Neither DM response to $\mathrm{P}$ in $\mathrm{Lc}$ and $\mathrm{Lt}$ nor its absence in $\mathrm{Lu}$ (Figure 1b) could be explained by root development because $P$ absorption of $\mathrm{Lt}$ was similar to $\mathrm{Lu}$ in the low and high $\mathrm{P}$ levels and both were higher than in Lc (Figure 3c); this does not support the relationship between species of deep or shallow rooting. These effects are related to the higher capacity of $\mathrm{Lu}$ to solubilize $\mathrm{P}$, which is acknowledged by many authors (Lowther, 1991; Trolove et al., 1996); one mechanism to solubilize $\mathrm{P}$ is exudation of carboxylic acids such as citrate (Bolan et al., 1997; Kirk et al., 1999), which can make possible the availability of P immobilized in soil organic forms. This explains why $\mathrm{Lu}$ did not respond to $\mathrm{P}$, but not why $\mathrm{Lt}$ responded to $\mathrm{P}$, which had significantly increased absorption the same as Lu (Figure 3c). Phosphorus absorption efficiency had a similar behavior in $\mathrm{Lu}$ and $\mathrm{Lt}$ when availability of this element in the soil was changed, but Lc showed a lower response than Lt when P increased (Figure 4b). The same was true with PUE (Figure 5b), but Lc showed higher values than the other two species. This difference in PUE explains the behavior of Lt which absorbed a greater quantity of $\mathrm{P}$, but did not utilize it as efficiently as the other two Lotus species. The growth of fewer roots (root DM) in the Vertisol than in the Andisol (Figure 1c) is the same as for the decrease in shoot DM. The value for Lc was much lower than Lt in the Vertisol; this can be explained by a greater loss of fine roots in Lc when separating the roots. The Verstisol is more highly compacted than the Andisol in which soil aggregates are more easily separated. There is a greater proportion of secondary root loss in the washing process. The above mentioned phenomenon affected Lu in both soils with the same intensity because it has finer roots. The higher root DM accumulation of the mean of the three species in the Andisol at both SWA levels (Figure 1d) is due to high macroporosity, low penetration resistance, low bulk density, good structural and soil aggregate conditions, high effective cation exchange capacity (ECEC), and high soil organic matter content (Kleber and Jahn, 2007). The negative effect of low SWA on root DM at both P levels (Figure 1e) is due to the intense water stress the plants were subjected to.

\section{Phosphorus absorption and utilization efficiency}

Lotus corniculatus maintained lower values of shoot $\mathrm{P}$ absorption than Lt and Lu (Figure 3a, 3b, and 3c), which clearly indicates that this species absorbs less $\mathrm{P}$, at least with the yields achieved in the present experiment. According to Acuña (2008), Lc exhibits lower shoot P concentration than Lt over a range of soil P levels, except for situations in which soil available $\mathrm{P}$ reaches very high levels and shoot $\mathrm{P}$ concentration for both species tends to be equal (Figure 2b). This cannot be associated with the type of rooting of the species because Lc (Grant and Niizeki, 2009) and Lt (Miñón et al., 1990) has deep roots, while Lu has a non-pivotal root system with a network of rhizomes, stolons, and fibrous roots (Hernández et al., 2005); this is not consistent with the higher AM colonization in Lc (Figure 6a). A possible explanation is related to interspecific genetic differences. Phosphorus availability and SWA largely determined PAE (Figure $4 \mathrm{~b}$ and d). Soil water availability indirectly affected PAE through $\mathrm{P}$ availability since soil $\mathrm{P}$ solubility benefited when SWA was not restrictive. Improved SWA most likely enhances $\mathrm{P}$ absorption because of the improved rate of $\mathrm{P}$ diffusion towards the root (Tinker and Nye, 2000). When the plant has a good water supply in low soil available $P$ conditions, it activates intrinsic mechanisms that allow optimizing $\mathrm{P}$ absorption through organic $\mathrm{P}$ solubilization in assimilable inorganic forms (García et al., 2008). Mean PAE (across species and SWA levels) was higher with low $P$ in both the Andisol and Vertisol (Figure 4c); this is partly explained by its relationship with higher AM colonization at low soil P (Figure 6b) because mycorrhized plants can absorb more $\mathrm{P}$ at lower $\mathrm{P}$ concentrations in the soil solution (Grant et al., 2005). On the other hand, PUE and PAE were affected by soil $\mathrm{P}$ availability (and indirectly by SWA) so that lower P availability leads to higher PUE (Figure $5 \mathrm{~b}$ and e). The behavior of PUE compared in the two soils corroborates this since low $\mathrm{P}$ in the Vertisol is less than low P in the Andisol (Figure 5d). However, the behavior between species is the most important because Lc exhibits a higher PUE (Figure 5b) and mycorrhization (Figure 6a) than the other two species, which means a higher DM production per unit of absorbed P. These results agree with those found by Mendoza (2001), who established that the mycorrhized Lc plants were more efficient in P utilization than mycorrhized Lt plants, thus producing higher aerial biomass yields per unit of $\mathrm{P}$ in soil with low available $\mathrm{P}$ content.

\section{CONCLUSIONS}

There are differences among species for DM production, response to $\mathrm{P}, \mathrm{P}$ absorption, PAE, and PUE. Lotus corniculatus and $\mathrm{Lu}$ respond to $\mathrm{P}$ whereas $\mathrm{Lt}$ does not. Lotus tenuis and Lu absorb more P than Lc. Phosphorus absorption efficiency of Lt and Lu are not affected by the level of soil P, but Lc shows a lower response than Lt when $\mathrm{P}$ increases. Phosphorus utilization efficiency and PAE vary in a similar pattern with Lc showing higher values than $\mathrm{Lt}$ and Lu. Lotus tenuis absorbs more P but does not utilize it as efficiently as Lc and Lu. High SWA affects PAE positively and PUE negatively by improving soil P solubility. Higher PAE in low P treatments is related to higher AM colonization. 


\section{ACKNOWLEDGEMENTS}

The authors thank José Oñate, INIA research assistant, for his technical support and Leandro Paulino, research staff of the Universidad de Concepción, for his help in determining AM colonization.

\section{LITERATURE CITED}

Acuña, H. 2008. Response to phosphorus, potassium and sulphur application on the productivity of Lotus spp. in two soil groups of central Chile. Lotus Newsletter 38:1-6.

Acuña, H., and G. Cuevas. 1999. Efecto de la altura y frecuencia de la defoliación, bajo corte y pastoreo, en el crecimiento y productividad de tres especies del género Lotus en suelos arcillosos. Agricultura Técnica 59:296-308.

Acuña, H., and L. Inostroza. 2012. Phosphous efficiency of naturalized Chilean white clover in a grazed field trial. Grass and Forage Science. doi:10.1111/j.1365-2494.2012.00879.x.

Acuña, H., L. Inostroza, M.P. Sánchez, and G. Tapia. 2010. Droughttolerant naturalized populations of Lotus tenuis for constrained environments. Acta Agriculturae Scandinavica, Section B - Plant and Soil Science 60:174-181.

Ahmad, Z., M.A. Gill, and R.H. Qureshi. 2001. Genotypic variations of phosphorus utilization efficiency of crops. Journal of Plant Nutrition 24:1149-1171.

Bolan, N.D., J. Elliot, P.E.H. Gregg, and S. Weil. 1997. Enhanced dissolution of phosphate rocks in the rhizosphere. Biology and Fertility of Soils 24:169-174.

Buresh, R.J., O.C. Smithson, and D.T. Hellums. 1997. Building soil phosphorus capital in Africa. p. 111-149. In Buresh, R.J., P.A. Sanchez, and F. Calhoun (eds.) Replenishing soil fertility in Africa. SSSA Special Publication, American Society of Agronomy and Soil Science Society of America, Madison, Wisconsin, USA.

Davis, M.R. 1991. The comparative phosphorus requirements of some temperate perennial legumes. Plant and Soil 133:17-30.

Escaray, F.J., A.B. Menendez, A. Gárriz, F.L. Pieckenstain, M.J. Estrella, L.N. Castagno, et al. 2012. Ecological and agronomic importance of the plant genus Lotus. Its application in grassland sustainability and the amelioration of constrained and contaminated soils. Plant Science 182:121-133.

Feng, G., Y.C. Songa X.L. Li, and P. Christie. 2003. Contribution of arbuscular mycorrhizal fungi to utilization of organic sources of phosphorus by red clover in a calcareous soil. Applied Soil Ecology 22:139-148.

García, I., R. Mendoza, and M.C. Pomar. 2008. Deficit and excess of soil water impact on plant growth of Lotus tenuis by affecting nutrient uptake and arbuscular mycorrhizal symbiosis. Plant and Soil 304:117-131.

Giovannetti, M., and B. Mosse. 1980. An evaluation of techniques for measuring vesicular-arbuscular infection in roots. New Phytologist 84:489-500.

Grant, C., S. Bittman, M. Monreal, C. Plenchette, and C. Morel. 2005. Soil and fertilizer phosphorus: Effects on plant P supply and mycorrhizal development. Canadian Journal of Plant Science 85:3-14.

Grant, W.F., and M. Niizeki. 2009. Chapter 6. Birdsfoot trefoil (Lotus corniculatus L.) p. 153-205. In R.J. Singh (ed.) Genetic resources, chromosome engineering, and crop improvement: Forage crops. CRC Press, Boca Raton, Florida, USA.

Hernández, S., M. Rebuffo, S. Arrivillaga, M. Jaurena, C. Labandera, D. Risso, and J. Ciliuti. 2005. Evaluation of the genotypeenvironment interaction in the establishment of Lotus uliginosus (Schkuhr) with soil-cores. Lotus Newsletter 35:120-130.

Hinsinger, P. 2001. Bioavailability of soil inorganic P in the rhizosphere as affected by root-induced chemical changes: A review. Plant and Soil 237:173-195.
Kaiser, C.J., and M.E. Heath. 1990. Big trefoil: A new legume for pastures on fragipan soils. p. 191-194. In Janick, J., and J.E. Simon (eds.) Advances in new crops. Timber Press, Portland, Oregon, USA.

Karandashov, V., and M. Bucher. 2005. Symbiotic phosphate transport in arbuscular mycorrhizas. Trends in Plant Science 10:22-29.

Kirk, G.J.D., E.E. Santos, and M.B. Santos. 1999. Phosphate solubilization by organic anion excretion from rice roots in aerobic soil: rates of excretion and decomposition, effects on rhizosphere $\mathrm{pH}$, and effects on phosphate solubility. New Phytologist 142:185200.

Kleber, M., and R. Jahn. 2007. Andosols and soils with andic properties in the German soil taxonomy. Journal of Plant Nutrition and Soil Science 170:317-328.

Klute, A. 1986. Water retention: Laboratory methods. p. 635-661. In Klute A. (ed.) Method of soil analysis. Part 1. Agronomy. Monograph 9. ASA and SSSA, Madison, Wisconsin, USA.

Lowther, W.L. 1991. Comparison of Maku lotus (Lotus pedunculatus)-based and clover (Trifolium spp.)-based swards with and without regular phosphorus fertilizer. New Zealand Journal of Agricultural Research 34:335-339.

Mendoza, R. 2001. Phosphorus nutrition and mycorrhizal growth response of broadleaf and narrowleaf birdsfoot trefoils. Journal of Plant Nutrition 24:203-214.

Mendoza, R., V. Escudero, and I. García. 2005. Plant growth, nutrient acquisition and mycorrhizal symbioses of a waterlogging tolerant legume (Lotus glaber Mill.) in a saline-sodic soil. Plant and Soil 275:305-315.

Mendoza, R.E., and E.A. Pagani. 1997. Influence of phosphorus nutrition on mycorrhizal growth response and morphology of mycorrhizae in Lotus tenuis. Journal of Plant Nutrition 20:625639.

Messa, A., R. Saldías, A. Castillo, J. Monza, O. Borsani, and M. Rebuffo. 2008. Seed yield components in F2 genotypes of interspecific hybrids of Lotus uliginosus and Lotus japonicus. Lotus Newsletter 38:62-63.

Miñón, D.P., G.H. Sevilla, L. Montes, and O.N. Fernández. 1990. Lotus tenuis: Leguminosa forrajera para la pampa deprimida. Instituto Nacional de Tecnología Agropecuaria (INTA), Unidad Integrada Balcarce, Balcarce, Argentina.

Miyasaka, S.C., and M. Habte. 2001. Plant mechanisms and mycorrhizal symbioses to increase phosphorus uptake efficiency. Communications in Soil Science and Plant Analysis 32:11011147.

Neumann, G., and V. Römheld. 1999. Root excretion of carboxylic acids and protons in phosphorus-deficient plants. Plant and Soil 211:121-130.

Ortega, R., and C. Rojas. 1998. Evaluación agronómica del efecto de fuentes fosfatadas en arroz inundado. Agricultura Técnica 58:2331.

Puentes, R., L.P. Wilding, and L.R. Drees. 1992. Microspatial variability and sampling concepts in soil porosity studies of Vertisols. Geoderma 53:373-385.

Rahman, M.H., A. Okubo, S. Sugiyama, and H.F. Mayland. 2008. Physical, chemical and microbiological properties of an Andisol as related to land use and tillage practice. Soil \& Tillage Research 101:10-19.

Russelle, M., R. McGraw, and R. Leep. 1991. Birdsfoot trefoil response to phosphorous and potassium. Journal of Production Agriculture 4:114-120.

Sadzawka, A., M.A. Carrasco, R. Demanet, H. Flores, R. Grez, M.L. Mora, y A. Neaman. 2007. Métodos de análisis de tejidos vegetales. $2^{\text {a }}$ ed. Serie Actas $\mathrm{N}^{\circ} 40.139$ p. Instituto de Investigaciones Agropecuarias INIA, Santiago, Chile.

SAS. 2004. SAS Version 9.1.2. SAS Institute, Cary, North Carolina, USA.

Seaney, R.R., and P.R. Henson. 1970. Birdsfoot trefoil. Advances in Agronomy 22:119-153 
Smith, S., I. Jakobsen, M. Grønlund, and F. Smith. 2011. Roles of arbuscular mycorrhizas in plant phosphorus nutrition: Interactions between pathways of phosphorus uptake in arbuscular mycorrhizal roots have important implications for understanding and manipulating plant phosphorus acquisition. Plant Physiology 156:1050-1057.

Steubing, L., R. Godoy, and M. Alberdi. 2002. Métodos de ecología vegetal. Editorial Universitaria, Universidad Austral, Valdivia, Chile.

Stolpe, N.B. 2006. Descripciones de los principales suelos de la VIII Región de Chile. Universidad de Concepción, Departamento de Suelos y Recursos Naturales, Chillán, Chile.

Striker, G.G., P. Insausti, A.A. Grimaldi, E.L. Ploschuk, and V. Vasellati. 2005. Physiological and anatomical basis of differential tolerance to soil flooding of Lotus corniculatus L. and Lotus glaber L. Plant and Soil 276:301-311.

Takahashi, S., and M.R. Anwar. 2007. Wheat grain yield, phosphorus uptake and soil phosphorus fraction after 23 years of annual fertilizer application to an Andosol. Field Crops Research 101:160-171.
Tang, C., and Z. Rengel. 2003. Role of plant cation/anion uptake ratio in soil acidification. p. 57-81. In Rengel, Z. (ed.) Soil acidity handbook. Marcel Dekker, New York, USA

Teakle, N.L., A. Amtmann, D. Real, and T.D. Colmer. 2010. Lotus tenuis tolerates combined salinity and waterlogging: maintaining $\mathrm{O}_{2}$ transport to roots and expression of an NHX1-like gene contribute to regulation of $\mathrm{Na}^{+}$transport. Physiologia Plantarum 139:358-374.

Tinker, P.B., and P.H. Nye. 2000. Solute movement in the rhizosphere. Oxford University Press, Oxford, UK.

Trolove, S.N., M.J. Hedley, J.R. Caradus, and A.D. Mackay. 1996. Uptake of phosphorus from different sources by Lotus pedunculatus and three genotypes of Trifolium repens. 2. Forms of phosphate utilised and acidification in the rhizosphere. Australian Journal of Soil Research 34:1027-1040.

Wittenmayer, L., and W. Merbach. 2005. Plant responses to drought and phosphorus deficiency: Contribution of phytohormones in root-related processes. Journal of Plant Nutrition and Soil Science 168:531-540 